Article

\title{
Experimental Analysis of Welded Rods with a Functionally Graded Material Approach
}

\author{
Ayse Nihan Basmaci ${ }^{1, *}$, Seckin Filiz ${ }^{1}$ (1) and Mümin Şahin ${ }^{2}$ \\ 1 Vocational School of Technical Sciences, Tekirdag Namik Kemal University, Tekirdag 59030, Turkey; \\ sfiliz@nku.edu.tr \\ 2 Department of Mechanical Engineering, Trakya University, Edirne 22180, Turkey; mumins@trakya.edu.tr \\ * Correspondence: anbasmaci@nku.edu.tr; Tel.: +90-0506-986-24-62
}

Received: 11 May 2020; Accepted: 30 May 2020; Published: 5 June 2020

\begin{abstract}
In recent years, with the development of welding methods, using these methods in manufacturing industry and in advanced engineering has become more popular. In this study, mechanical properties of rods obtained by friction welding and electric arc welding are compared. Hence, three specimens with different material properties are manufactured, two of which are welded by friction welding and one of which is welded by electric arc welding. These three specimens are adapted to the ASTM E8-04 standard with the help of a universal lathe. Moreover, the tensile stress values and the elasticity modulus of all these specimens are obtained as a result of tensile tests. Accordingly, the effects of the type of welding and material properties used in manufacturing on the mechanical behavior of the specimens are examined. In addition, specimens taken from the cracked surfaces of the pieces broken from the specimens as a result of the tensile test are examined with SEM (scanning electron microscopy). These examinations reveal the microstructure of the specimens. The elemental distribution data obtained as a result of examinations with SEM and the mechanical property data obtained as a result of tensile tests support each other. Furthermore, effects of a heat affected zone (HAZ) on the mechanical properties of the rod are investigated as a functionally graded material.
\end{abstract}

Keywords: electrical arc welding; elasticity moduli; functionally graded material; mechanical properties; rotary inertia friction welding; tensile test

\section{Introduction}

Due to its ease of use, electric arc welding has a wide range of applications in the manufacturing industry. Material properties in electric arc welding are affected by high temperature. On the other hand, the structure turns out from indicating ductile material properties and starts indicating brittle material properties. The material feature of the welded structure after cooling down to room temperature depends on which temperature it starts to cool. The higher the temperature at which this structure begins to cool, the more brittle a material property it will have.

Since the welding is a process performed at high temperatures, the mechanical properties of the structure from which the welding is made are affected by this process. The high temperature formed during the welding process affects both the welding point and the neighbors of that point. The heat affected zone (HAZ) occurs as a result of these effects caused by this high temperature. This formation is explored in [1,2]. The microstructure and hardness of HAZ of the MAG (Metal Active Gas)-welded structure is investigated in [3]. The high temperature mechanical properties of weld metals are examined in [4]. The negative effect of temperature on mechanical properties can be seen in [5]. It was investigated how the welding process, by providing heat inputs from an externally applied source, affects the mechanical properties of the structure in $[6,7]$. 
Examples of rotary inertia friction welding applications include compressor rotors and drill bits for aircraft engines. The rapid development shown by the friction welding method is due to the features that differ from conventional welding methods. The first of these features is that no extra heat source is required in the friction welding. In addition, the second feature is that the friction welding process begins when the welding temperature reaches a temperature close to the melting temperature. Microstructure properties of the structures produced by welding processes show the interaction between the high temperature during the process and the material properties of the structure. Friction welding, which is one of the rare welding methods that can be applied to similar materials, has become popular in recent years and many studies have been done on this subject in recent years [8,9]. Microstructures of specimens produced by friction welding are examined in detail in [10-13]. In [14-18] various applications related to friction welding have been studied. In [19,20], the mechanical properties of the structures produced by using friction welding from parts with different properties are examined by tensile tests.

Studies on microstructures and mechanical structures obtained by combining two different materials with arc welding are also available in the literature [21]. In addition, the investigation of both microstructure and mechanical properties of structures obtained by combining different materials with friction welding is another study subject [22-33]. In [34,35], microstructure properties of materials of the same type are studied.

By making a nitrogen reinforcement to the welding zone of the steel used in the manufacture of another structure, the mechanical properties of the structure were tried to be improved and as a result, the structure was made to be hard outside and partially soft inside. The cross section of this structure is taken and if this section is examined, it is concluded that the new structure formed is a functionally graded material (FGM) [21]. It should be noted that, there are many other studies related to FGM in the literature [36-38]. There are many theoretical examples of the thermal behavior and mechanical analysis (vibration, wave propagation, bending and buckling) of axially FGM in the literature [39-43]. The purpose of this study is to establish a link between theoretical and experimental studies. In previous studies, the heat affected zone was not designed as an FGM, and this creates a literature gap in this field. The novelty of this study is to fill the gap in this field and provide data for the benefit of scientists working theoretically.

In this study, tensile experiments are applied to the specimens produced by combining two different pair of rods with friction and electric arc welding. In addition, material microstructures of these specimens are examined with scanning electron microscopy (SEM). These examinations provide an idea about Young's modulus (modulus of elasticity), one of the most important mechanical properties of the material. Furthermore, with the help of SEM, the effects of different welding types used on the internal structures of the specimens produced are examined. In summary, this study can be grouped under two main headings as manufacturing and experimental analysis.

\section{Materials and Methods}

The proposed friction welded structure is shown in Figure 1. This welded structure consists of three segments. These three segments are called heat unaffected metal, the heat affected zone (HAZ) and the welding pool, respectively. As a result of the different temperature interactions of these three segments in the welding process, the mechanical properties $(E, \rho)$ of each segment are different from each other. Here, $\mathrm{E}$ is the elastic modulus and $\rho$ is density per length. Moreover, the central region (welding pool) of this structure is the region that is most exposed to temperature; it also negatively affects the mechanical properties of the structure. Since the interaction of the structure with temperature has an effect on the mechanical properties of the structure, the cooling method of the structure is also considered as an important parameter after the friction welding process. The cooling method also affects the inner structure of the central zone. 


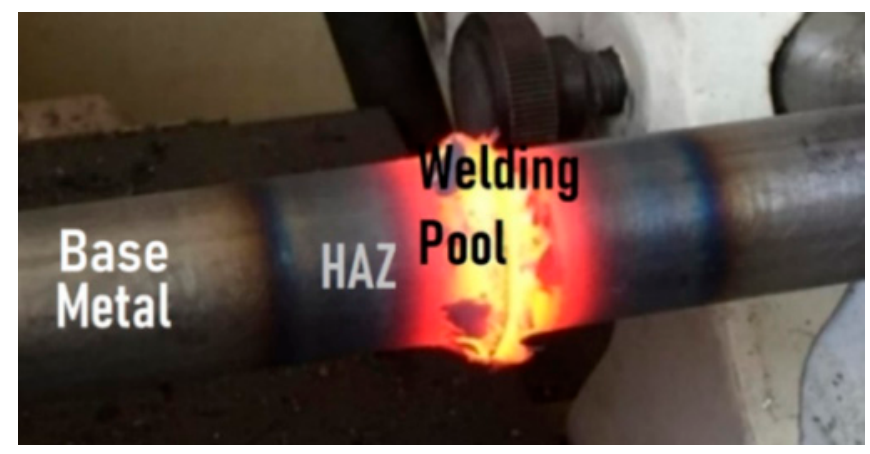

Figure 1. Air-cooled rotary inertia friction welded steel—steel rod.

The production phase of friction welding on the lathe is shown in Figure 2a. The rotating part in this phase is just the lathe chuck. One of the two parts connected to the two ends of the lathe rotates while the other does not. The fixed part presses the rotating part by applying a translational motion to the rotating part.
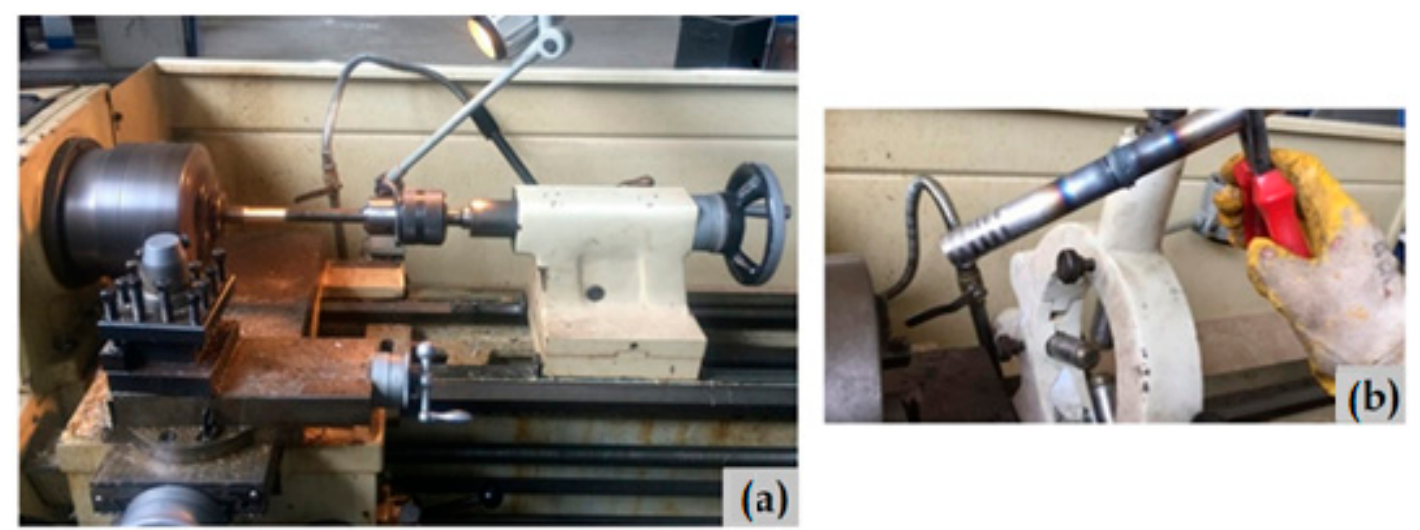

Figure 2. (a) Universal lathe machine. (b) Rotary friction welded steel—steel rod.

The effect of the high temperature applied during the welding process on the friction welded structure can be seen in Figure $2 b$.

In Figure 3, an image of the electric arc welding process, which is applied by using a rutile electrode at 100 amperes to the steel structures, is given.
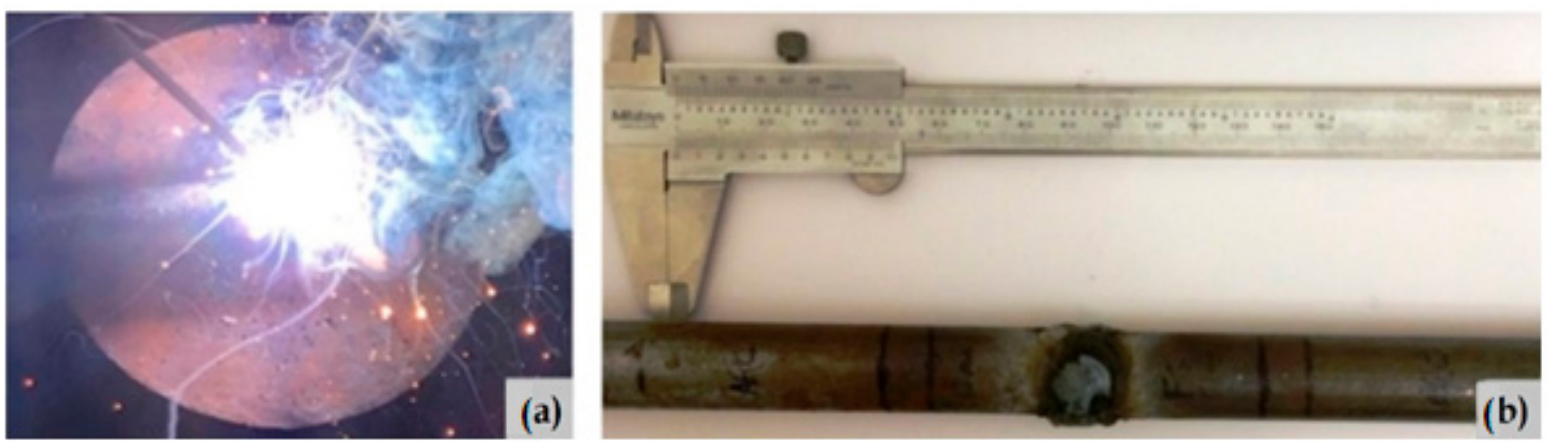

Figure 3. (a) Electric arc welding process and (b) electric arc welded steel—steel rod.

The structures produced by applying various welding processes are turned into tensile specimens using a lathing process (Figure 4a). These structures are processed according to ASTM E8M-04 standard (Figure 4b). 


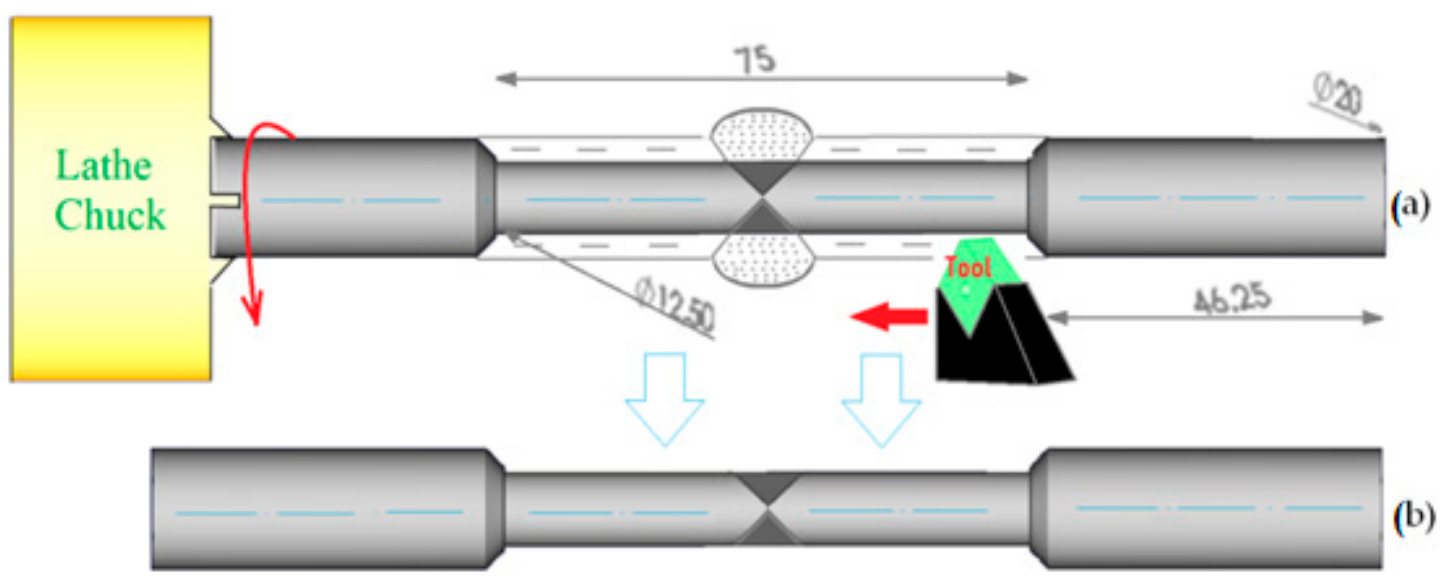

Figure 4. (a) Lathing process of welded rod and (b) ASTM E8M-04 rod specimen.

Two specimens obtained as a result of the friction welding process and one specimen obtained as a result of the electric arc welding process can be seen in Figure 5. In the macroscopic examination of the welding pool of the structure is given in Figure 3, it can be clearly seen that this structure is welded using an additional metal (electrode). Three different specimens produced as a result of various welding processes can be seen in Figure 5. The elastic modulus of the specimens is obtained by tensile test operations applied to these specimens. Thus, the modulus of elasticity values, one of the mechanical property values, is examined.

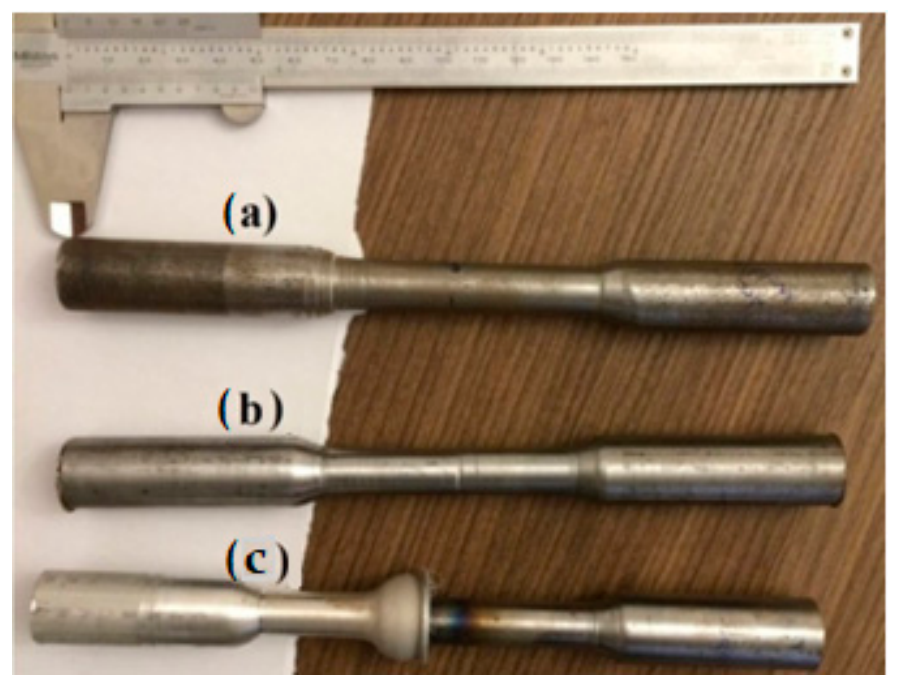

Figure 5. (a) Arc welded specimen, (b) steel-steel friction welded specimen and (c) aluminum-steel friction welded specimen.

According to the tensile test process applied to the specimen obtained in Figure 6, elastic modulus and toughness values of the specimens obtained with different welding types can be seen. In this figure, (a) indicates the specimen obtained with the electric arc welding of two steel materials, (b) indicates the specimen obtained with the electric arc welding of two steel materials and (c) indicates the specimen obtained with the friction welding of steel (St 37-2) -aluminum (Al 6082) materials. As can be seen in Figure 6, the elasticity module for the specimen given in (b) has the highest value compared to the specimens given in (a) and (c). In addition, the specimen given in (a) has the highest toughness value compared to the specimens given in (b) and (c). 


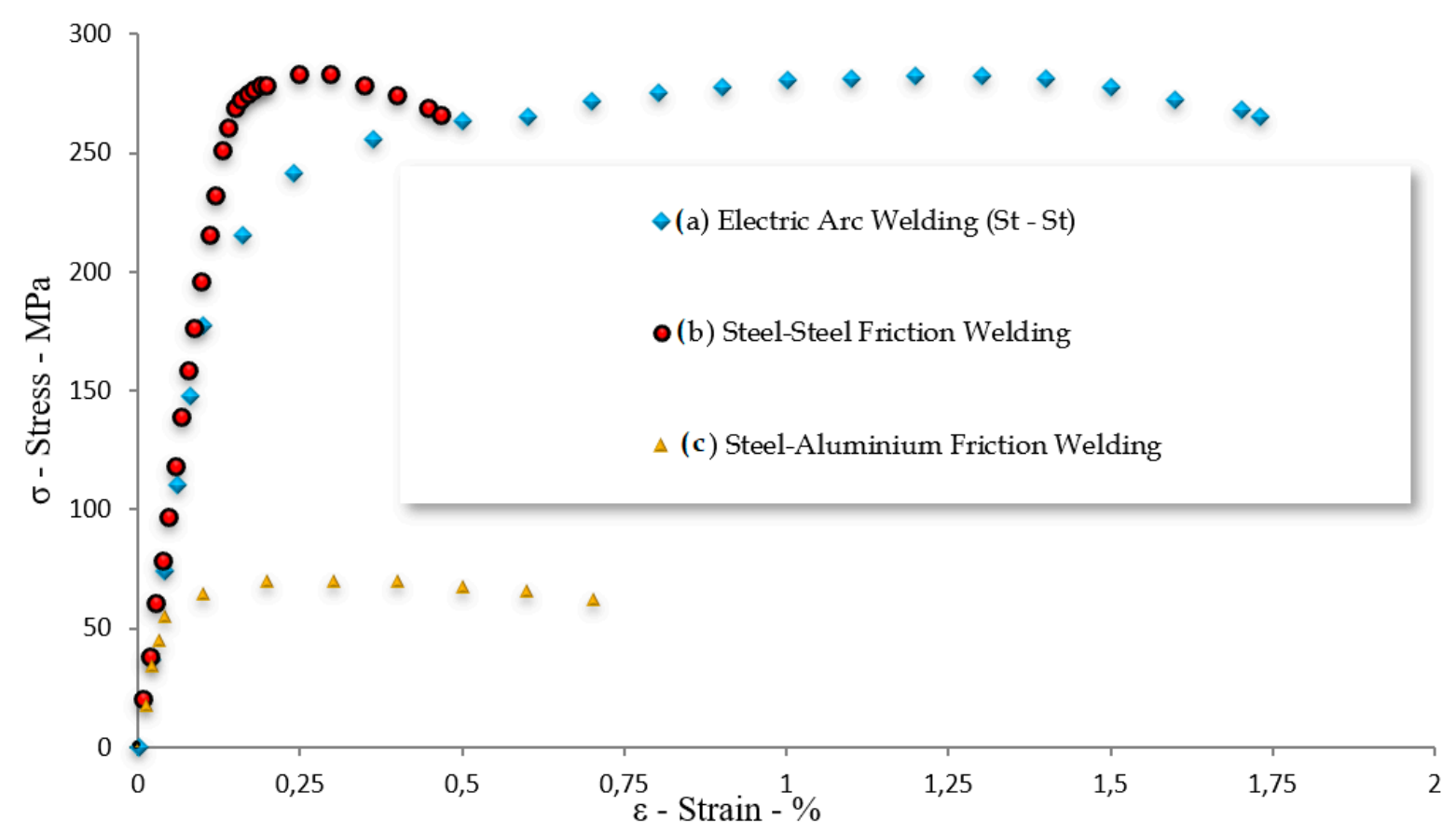

Figure 6. Tensile test of specimens: (a) Arc welded material and $(\mathbf{b}, \mathbf{c})$ friction welded specimen.

These three sampling breaks at the end of the tensile tests, and the last situation that they have, come after the tensile tests are given in Figure 7. As can be clearly seen in Figure 7a, the base metal part and the welding part are separated from each other after the tensile test of the specimen. In addition, this specimen contains base metal in the central part and welded material in the outer sides of the specimen. As can be seen in Figure 7b, the successful friction welding process in the manufacture of the specimen ensures that the macro structural properties of the separation surface occurring after the tensile test in the specimen can be observed with the naked eye. The high temperature caused by the friction welding process applied during the manufacture of the specimen given in Figure $7 \mathrm{c}$ enables the aluminum part of the specimen to wrap over the steel part of the specimen.
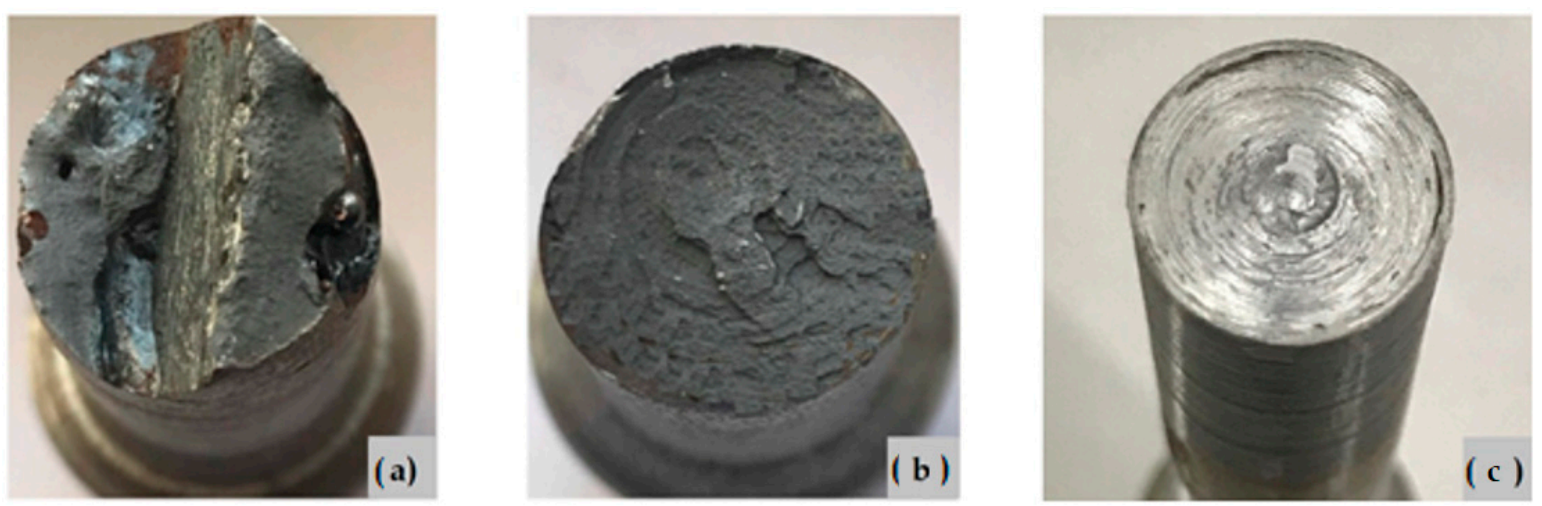

Figure 7. Cross-sectional view of broken specimens using tensile testing: (a) Broken electric arc welded specimen, (b) friction welded broken steel specimen and (c) broken aluminum specimen.

In the electron microscope, SEM, microstructures and element percentages of specimens can be examined. The data obtained as a result of these examinations enable the mechanical properties of the specimens to be determined. Microstructures of two steel specimens produced by friction welding and electric arc welding processes given in Figure $7 \mathrm{a}, \mathrm{b}$ are monitored on a computer screen with the help of SEM. The image on the computer screen obtained in the first examination with SEM reveals how the 
microstructure of the steel specimen given in Figure 8 is affected by the electric arc welding process it is subjected to during the manufacture of this specimen.
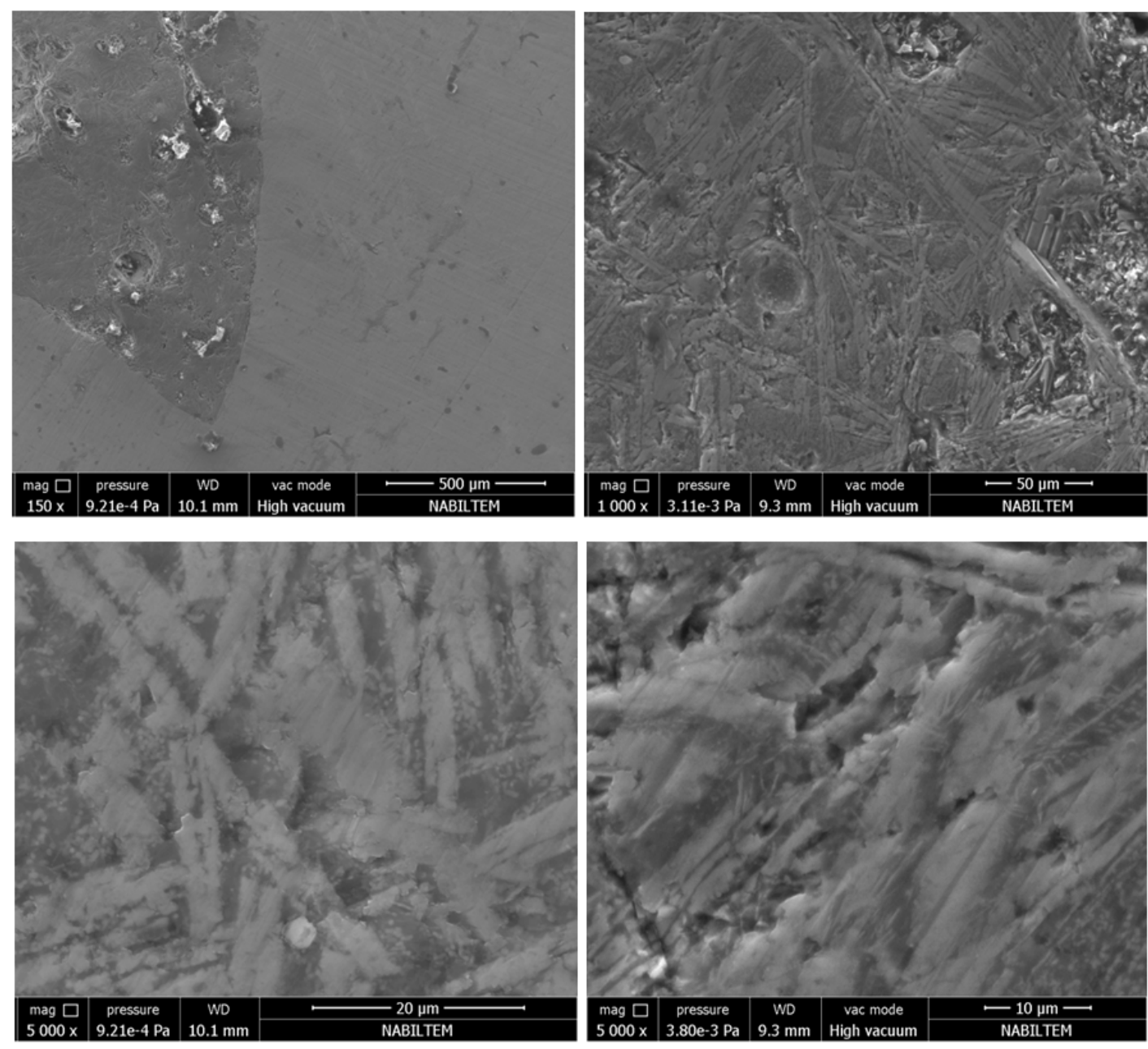

Figure 8. Scanning electron microscope test of the electric arc welded rod.

The microstructure given in Figure 9 appears to be affected by a lower temperature around the melting point compared to the microstructure given in Figure 8. Therefore, the lamella structure is not seen in Figure 9. 

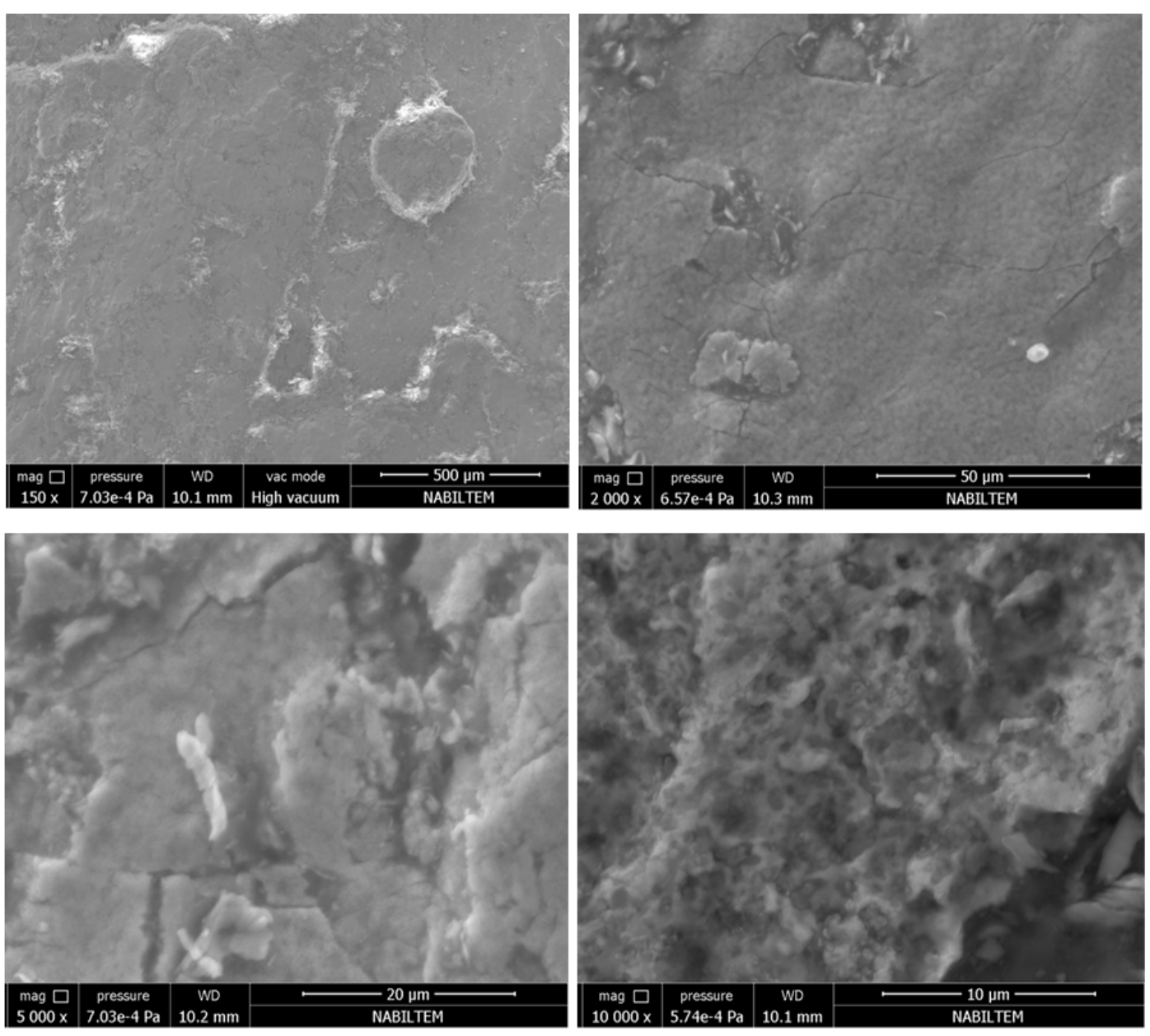

Figure 9. Scanning electron microscope test of the friction welded rod.

The carbon percentages in the structure of the specimens produced by different welding methods are given in Tables 1 and 2. The values given in Table 1 belong to the specimen obtained by electric arc welding; the values in Table 2 include the values for the specimen produced by friction welding. It is seen in Table 1 that the percentage of $C$ obtained in the structure of the specimen obtained by the electric arc welding is calculated as approximately $12 \%$. With the increase in the C percentage in the structure of the produced specimen, it is seen that the specimen examined has become more fragile. It is seen that the percentage of $C$ in the structure of the specimen produced by the friction welding method in Table 2 is approximately $21 \%$. The increase in the percentage of $C$ in the structures of the specimens examined is predicted to have a negative effect on the toughness values of the structures, and this issue will be discussed in more detail in the next section. 
Table 1. (a) EDAX ZAF spectrum and (b) element quantification of the electric arc welded rod.

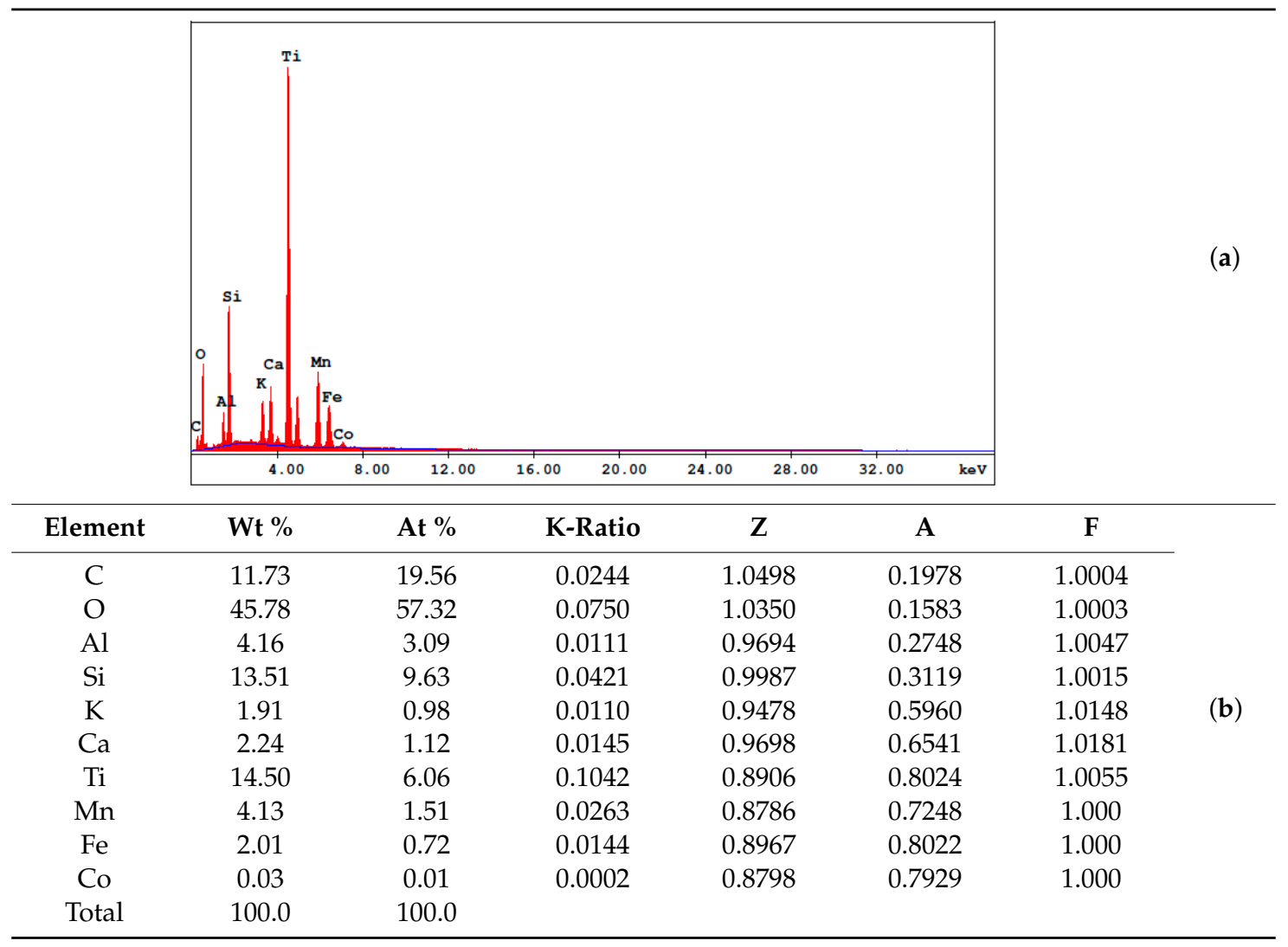

Table 2. (a) EDAX ZAF spectrum and (b) element quantification of the friction welded rod.

\begin{tabular}{cccccccccc|c|c}
\hline \\
\hline
\end{tabular}

When the microstructures of these two specimens are examined with a scanning electron microscope, the difference between the structures of both specimens is clearly visible. The specimen produced by friction welding has a more homogeneous structure compared to the specimen obtained by electric arc welding, since no material is added from the outside during the manufacturing phase. It is shown in the next section that the data obtained by tensile testing also support these findings obtained by scanning electron microscopy. 


\section{Results and Discussions}

Functionally grading is often observed in continuous structures. Rods with different properties are produced by a welding method and non-homogeneous structures are created. As previously mentioned and applied, in the production of these types of structures, friction welding methods are used. Parts of friction welding strength and other mechanical properties are not examined by some researchers [33-35]. Optimized friction welding conditions $70-80 \%$ hardness and poor mechanical properties are obtained by welding component friction-like materials [37]. Some examples of friction induced parts are: drill bits, pump shafts, drive shafts, piston rods, hydraulic cylinders and high torque drive shafts.

Several products manufactured by friction welding are shown in Figures 10-12. These products are used in many different fields from the aerospace industry to the automotive industry.
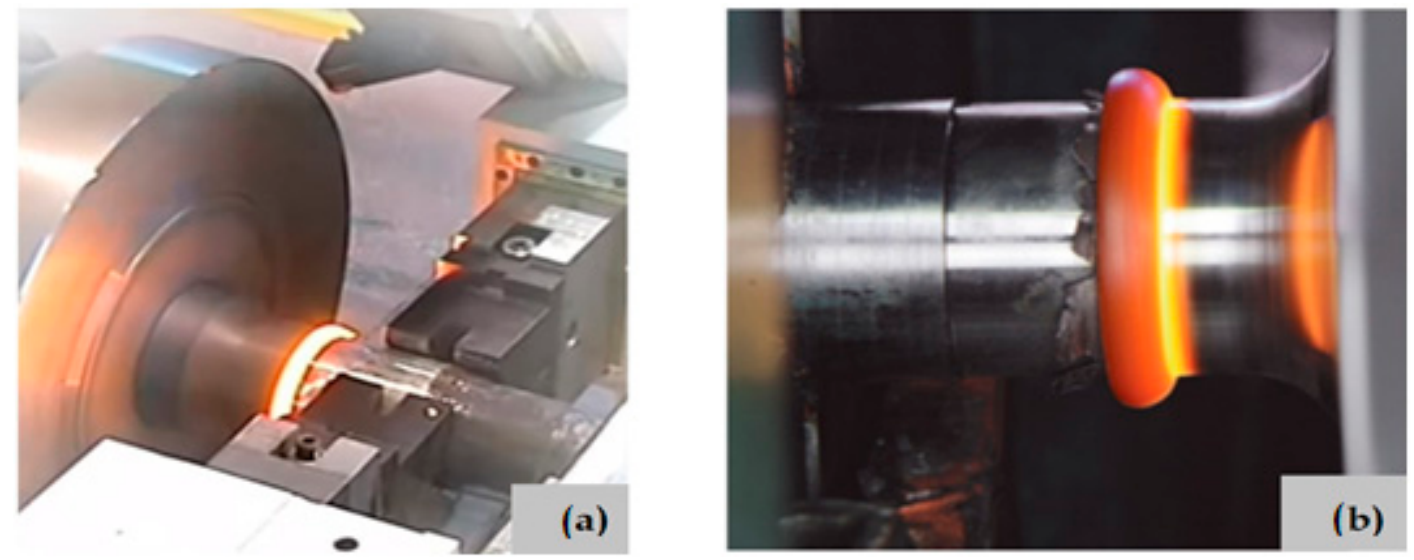

Figure 10. (a) Bellino Srl Company and (b) Keller und Knappich Augsburg Company (KUKA).

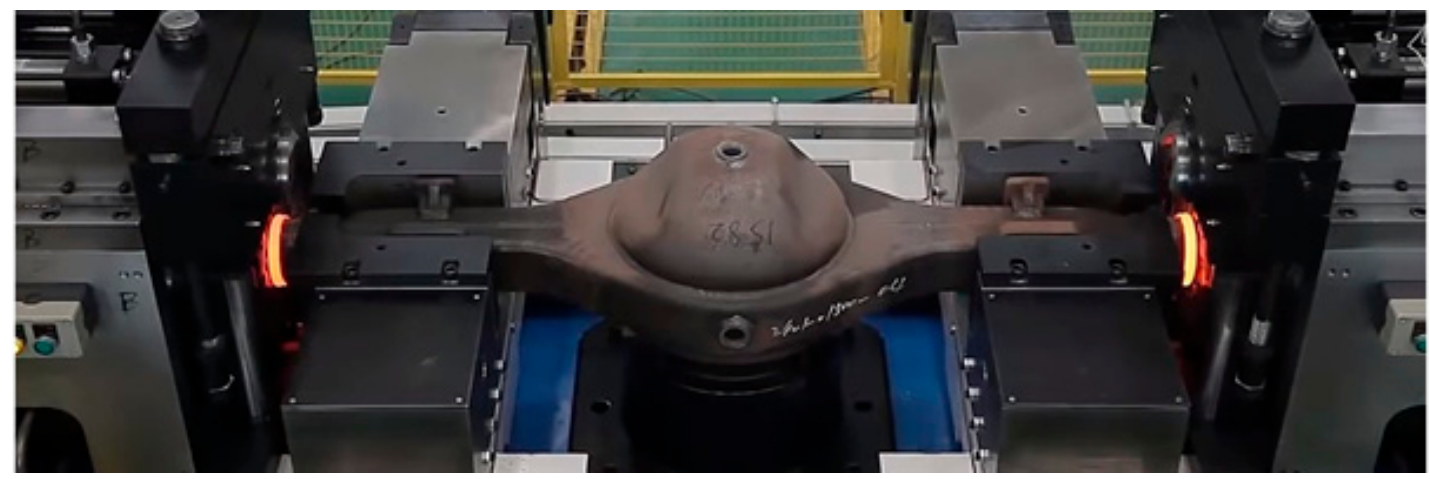

Figure 11. Friction welding of axles (China RCM).
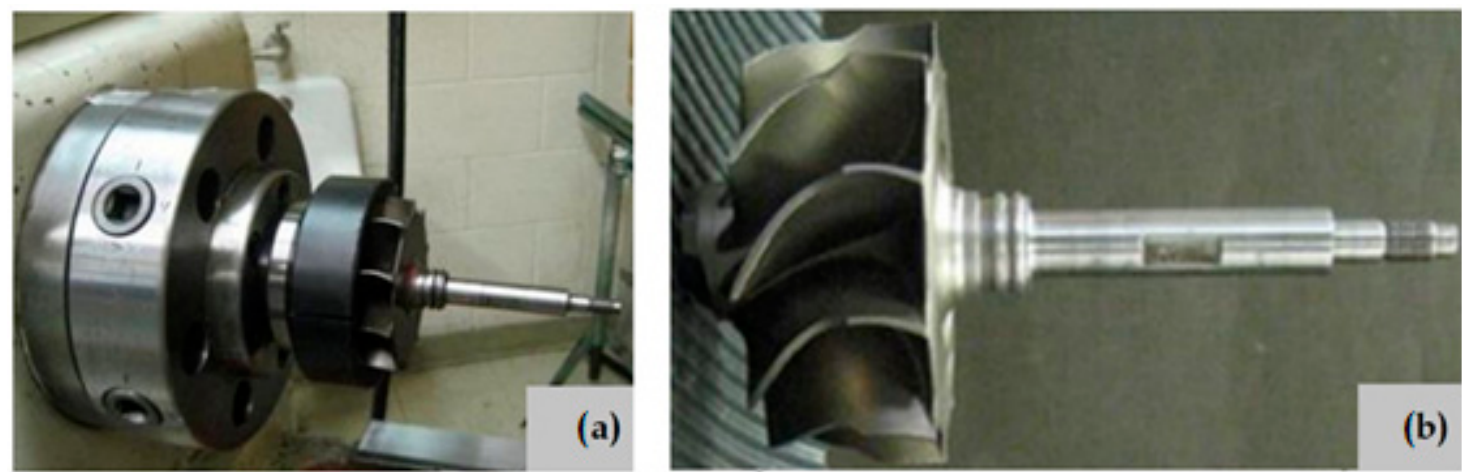

Figure 12. (a) Bellino Srl Company and (b) Keller und Knappich Augburg Company (KUKA); friction welding of Axles (China RCM). 
As can be seen in Figure 11, friction welding is made by placing a fixed axle in the middle of two different moving parts. This is an application of the automotive industry.

In Figure 12, there is a turbine wheel used in aerospace applications. It can be clearly seen that turbine blades are produced by using friction welding.

In 1987, in order to develop information about thermal stresses in functionally graded materials, the Research on the Basic Technology for the Development of Functionally Gradient Materials for Relaxation of Thermal-Stress Project was started. The goal of this project is thermal-shielded structural for advance aerospace programs. Many advanced materials have been produced by this project. As a result of this project, thermo-mechanical properties of FGMs (such as thermal shock, fatigue resistances, etc.) have been developed [44]. In addition, in a study conducted in recent years, functional graded tools are created with specimens obtained from friction welding [45]. In our article, the microstructure and mechanical properties of the materials affected by the friction and welding effect are examined by considering them as FGM design.

The mechanical properties (specific to the elasticity module) of the heat-affected areas of the specimens are shown in Figure 13. These mechanical properties (specifically for the modulus of elasticity) are designed as functionally graded and Figure 14 is obtained. In this design, as can be seen in the tensile test specimens, it is assumed that the rods are welded exactly in the middle. When these three specimens are examined, it is seen that the functionally grading occurs exponentially in the electric arc welded specimen and linearly in the friction welded specimen. As the reason for this situation, in the electric arc welding, the temperature of the welding spot (welding pool) rises up to $3000{ }^{\circ} \mathrm{C}$. That is, the melting temperature of the steel is doubled. Therefore, in electric arc welding, the mechanical properties of the welding spot (welding pool) are adversely affected.

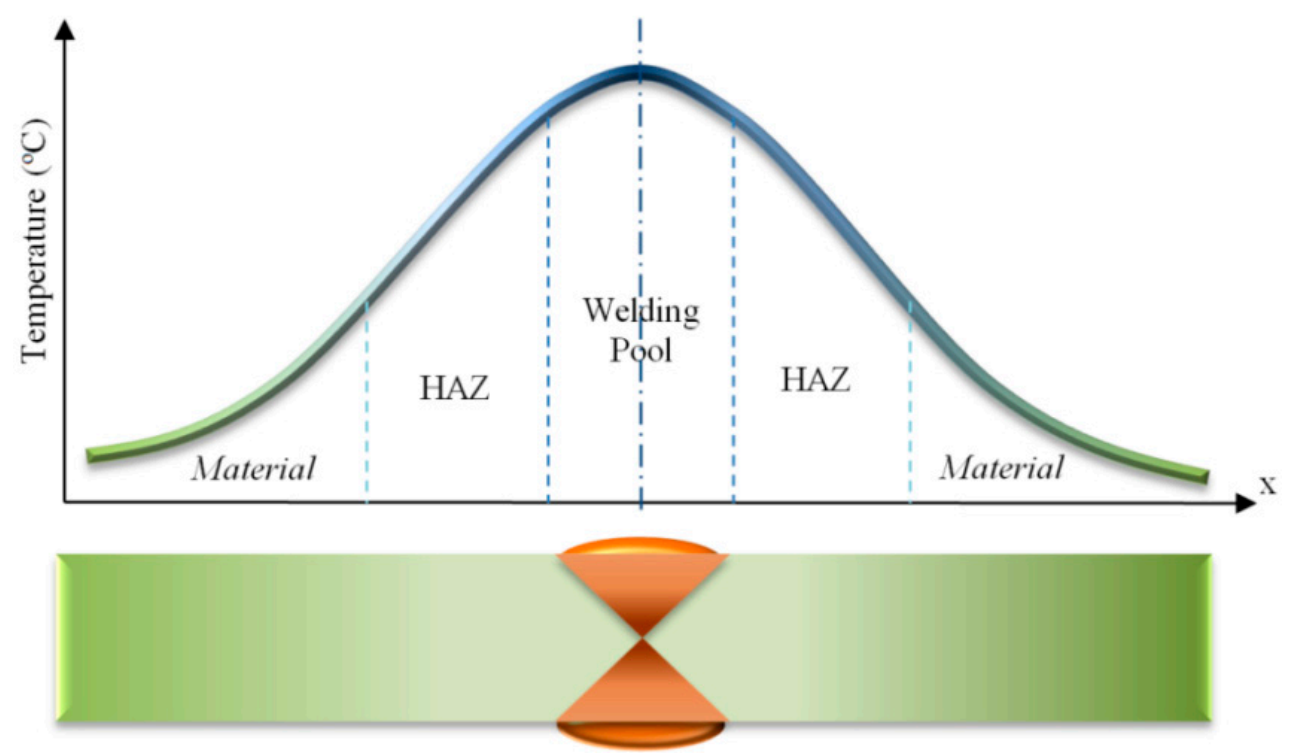

Figure 13. Heat affected zone properties. 

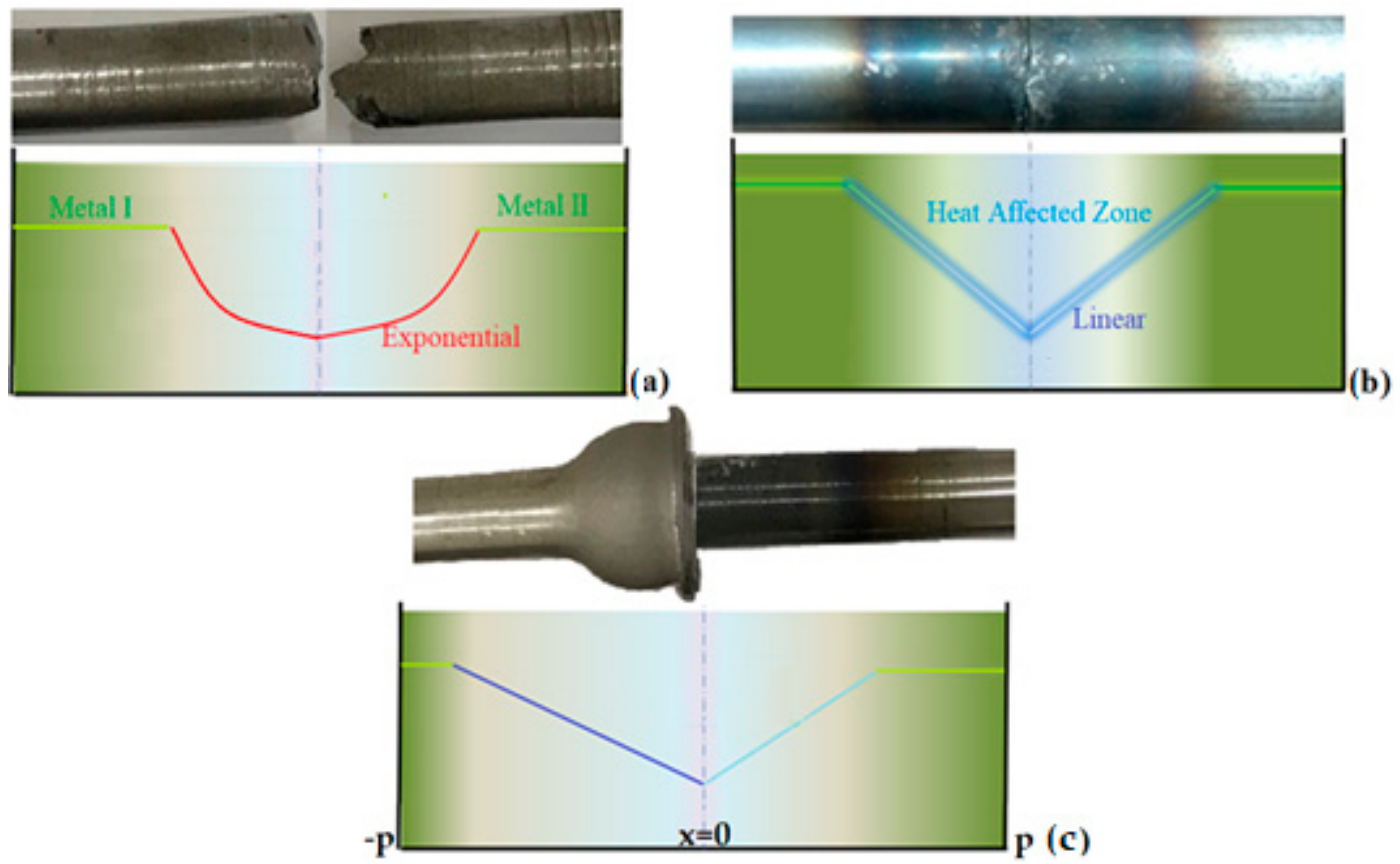

Figure 14. Functionally linear and exponential grading of the heat affected zone, (a) Arc welded specimen, (b) steel-steel friction welded specimen, (c) aluminum-steel friction welded specimen.

Based on Figure 15, the elasticity modules of these three specimens are calculated and the results are given in Table 3. The value of elasticity modules given in Table 3 obtained with the help of experimental analysis methods reveals the negative effect of high temperature on mechanical properties when compared with theoretical values. Since the distance of the specimen to the welding pool is inversely proportional to the temperature parameter, it is assumed that this proportion will also have a functionally grading effect on the modulus of elasticity and the design is carried out within the framework of this assumption.

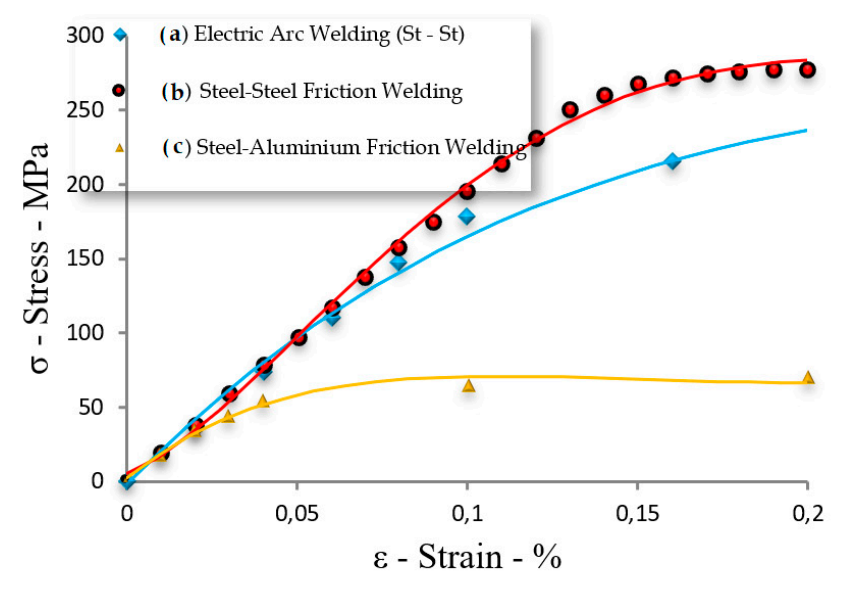

(a)

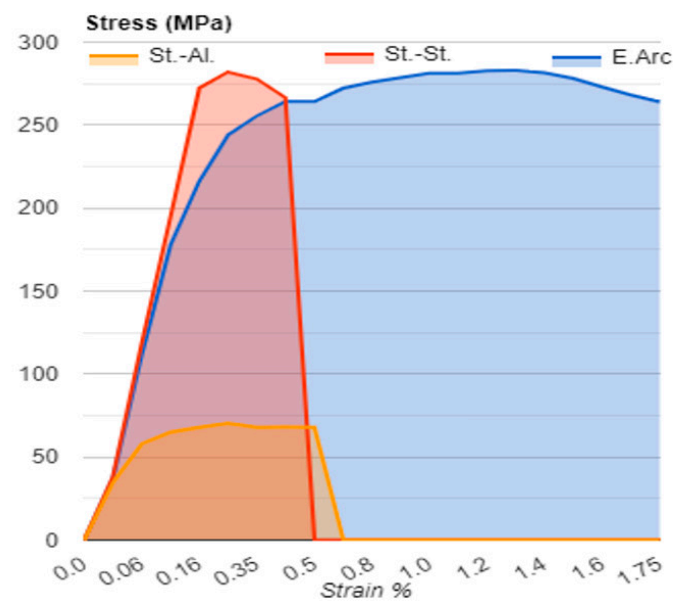

(b)

Figure 15. (a) Determination of the elasticity moduli of welded rod and (b) toughness of welded rods. 
Table 3. Modulus of elasticity of different functionally graded cases.

\begin{tabular}{|c|c|c|c|c|c|}
\hline \multirow[b]{2}{*}{ Case No } & \multicolumn{3}{|c|}{ Modulus of Elasticity (GPa) } & \multicolumn{2}{|r|}{ Functionally Grading } \\
\hline & Metal I & Metal II & $H A Z$ & $\begin{array}{c}\text { Type } \\
(\text { HAZ ratio- } \gamma)\end{array}$ & Function Equation \\
\hline (a) & 201 & 201 & 181 & Exponential $(\gamma=181 / 201)$ & $E_{H A Z} e^{\frac{\ln \left(E_{\text {BaseMetal II II }}\right)-\ln \left(E_{\text {HAZ }}\right)}{p} x}$ \\
\hline (b) & 201 & 201 & 195 & Linear $(\gamma=195 / 201)$ & $\frac{\left(E_{\text {BaseMetal II }}-E_{H A Z}\right)}{p} x+E_{H A Z}$ \\
\hline (c) & 201 & 69 & 45 & Linear $(\gamma=45 / 69)$ & $\frac{\left(E_{\text {BaseMetal II }}-E_{H A Z}\right)}{p} x+E_{H A Z}$ \\
\hline
\end{tabular}

The data obtained as a result of tensile tests are: $181 \mathrm{GPa}, 195 \mathrm{GPa}$ and $45 \mathrm{GPa}$, respectively. According to these elasticity module values obtained as a result of tensile tests, the elasticity modules in the HAZ regions of these three specimens analyzed are determined $\left(E_{S t}=201 \mathrm{GPa}, \mathrm{E}_{\mathrm{Al}}=69 \mathrm{GPa}\right)$.

In Table 3, in Case (a), it is assumed that the functionally grading is also exponential, based on the assumption that the temperature rise occurs exponentially. The functionally grading characteristic given in Table 3, Case (b) is assumed to be linear. Since the specimen given in Table 3, Case (c) is a friction welded structure, the functionally grading characteristic of this structure is assumed to be linear. Since two different materials are used in the production of this specimen, the functions of both sides of the specimen have the same linear characteristic; however, it has different slopes (Figure 14c).

If the specimens are compared according to the tensile test data, it is concluded that the welding process performed between two materials of the same type given in Table 3, Case (a) is more successful than the welding process between two materials of different types given in Table 3, Case (c). The $\gamma$ parameter expresses the functionally grading method, defined as $\gamma=\frac{E_{H A Z}}{E_{\text {Base Metal }}}$. Value of $\gamma$ is 0.9 in Table 3, Case (a), however, it decreases to 0.65 in Table 3, Case (c).

The temperature dependent properties for the material are indicated by $\mathrm{P}$; these properties are $P=P_{0}\left(P_{-1} T^{-1}+1+P_{1} T+P_{2} T^{2}+P_{3} T^{3}\right)$, where $\mathrm{T}=\mathrm{T}_{0}+\Delta \mathrm{T}$. The values at $\mathrm{T}_{0}=300 \mathrm{~K}$ are given in Table 4 .

Table 4. Elasticity modulus $(E)$, mass per density $(\rho)$, coefficient of thermal expansion $(\alpha)$ and thermal conductivity ( $\kappa$ ) of Steel (SUS 304) depending on temperature effect [46].

\begin{tabular}{cccccccc}
\hline Material & Property & $\mathbf{P}_{\mathbf{- 1}}$ & $\mathbf{P}_{\mathbf{0}}$ & $\mathbf{P}_{\mathbf{1}}$ & $\mathbf{P}_{\mathbf{2}}$ & $\mathbf{P}_{\mathbf{3}}$ & $\left.\mathbf{P}_{(\mathbf{a t}} \mathbf{3 0 0} \mathbf{K}\right)$ \\
\hline & $\mathbf{E}(\mathbf{P a})$ & 0 & $201.04 \times 10^{9}$ & $3.079 \times 10^{-4}$ & $-6.534 \times 10^{-7}$ & 0 & $207.7877 \times 10^{9}$ \\
SUS304 & $\boldsymbol{v}$ & 0 & 0.3262 & $-2.002 \times 10^{-4}$ & $3.797 \times 10^{-7}$ & 0 & 0.3178 \\
Steel & $\boldsymbol{\rho}\left(\mathbf{k g} / \mathbf{m}^{\mathbf{3}}\right)$ & 0 & 8166 & 0 & 0 & 0 & 8166 \\
& $\boldsymbol{\alpha}\left(\mathbf{K}^{-\mathbf{1}}\right)$ & 0 & $12.33 \times 10^{-6}$ & $8.086 \times 10^{-4}$ & 0 & 0 & $15.321 \times 10^{-6}$ \\
& $\boldsymbol{\kappa}(\mathbf{W m} / \mathbf{K})$ & 0 & 12.04 & 0 & 0 & 0 & 12.04 \\
\hline
\end{tabular}

The microstructure of a welded material is examined in detail and how the heat affected zone is affected by the temperature is explained [47]. In this context, the HAZ can theoretically be designed as an FGM.

Experimental data obtained from tensile tests revealed that the specimen with the highest toughness value is the specimen produced by the electric arc welding process, while the specimen with the lowest toughness value is the specimen consisting of two different materials produced by friction welding process.

\section{Conclusions}

The data obtained as a result of the experimental analysis carried out within the scope of this study reveal the pros and cons of the conventional electric arc welding process compared to the friction welding process. The experimental results regarding the electric arc welding process reveal that the modulus of elasticity is affected by a small amount of high temperature applied during the process. The data obtained as a result of the tensile test reveals that the toughness value obtained from the 
specimen produced by the electric arc welding process is three times the toughness value obtained from the specimen produced by the friction welding process. In addition, the friction welding process is important in that it allows two structures with different properties to be combined. This study can also lead to different studies to follow. In further studies, the electric arc welding process can be compared with other different welding methods and the data obtained as a result of this comparison can be applied to the bending, buckling and vibration characteristic equations of beams, bars and plates. In addition, the mechanical data obtained by performing three-point bending test can be discussed.

Author Contributions: Conceptualization, S.F. and A.N.B.; formal analysis, S.F. and A.N.B.; investigation, A.N.B., S.F. and M.Ş.; methodology, S.F. and A.N.B.; resources, A.N.B., S.F. and M.Ş.; validation, A.N.B., S.F. and M.Ş.; writing-original draft, A.N.B. and S.F.; writing-review and editing, A.N.B. and S.F. All authors have read and agreed to the published version of the manuscript.

Funding: This research received no external funding.

Acknowledgments: In this study, the data were obtained as a result of tests performed in the İstanbul TeknoLAB firm and Tekirdag Namik Kemal University NABİLTEM laboratories. In addition, FreeCAD 0.18 program and Microsoft Word were used in the drawings.

Conflicts of Interest: The author declares no conflict of interest.

\section{References}

1. Wallner, F.; Schimböck, R.; Rauch, R. Verbesserte und neue TM-Stähle für geschweißte Konstruktionen (Advanced and new TMCP-steels for welded constructions). In Proceedings of the Internationale Schweißund Fertigungstechnische Tagung, Vienna, Austria, 25-26 May 2000. (In German).

2. Easterling, K. Introduction to the Physical Metallurgy of Welding; Butterworth-Heinemann: Oxford, UK, 1992.

3. Lahtinen, T.; Vilaça, P.; Peura, P.; Mehtonen, S. MAG welding tests of modern high strength steels with minimum yield strength of $700 \mathrm{MPa}$. Appl. Sci. 2019, 9, 1031. [CrossRef]

4. Rezaeian, A.; Keshavarz, M.; Hajjari, E. Mechanical properties of steel welds at elevated temperatures. J. Constr. Steel. Res. 2019, 23, 105853. [CrossRef]

5. Roshanghias, A.; Barzegari, M.; Kokabi, A.-H.; Mirazizi, M. The effects of functionally graded material structure on wear resistance and toughness of repaired weldments. Mater. Des. 2011, 32, 892-899. [CrossRef]

6. Wang, H.; Qin, G.; Geng, P.; Ma, X. Interfacial microstructures and mechanical properties of friction welded Al/steel dissimilar joints. J. Manuf. Process. 2020, 49, 18-25. [CrossRef]

7. Sahin, M.; Akata, H.-E. An experimental study on friction welding of medium carbon and austenitic stainless steel components. Ind. Lubr. Tribol. 2004, 3, 122-129. [CrossRef]

8. Grant, B.; Preuss, M.; Withers, P.-J.; Baxter, V.; Rowlson, M. Finite element process modelling of inertia friction welding advanced nickel-based superalloy. Mater. Sci. Eng. A Struct. 2009, 513-514, 366-375. [CrossRef]

9. Damodaram, R.; Raman, S.-G.-S.; Rao, K.-P. Microstructure and mechanical properties of friction welded alloy 718. Mater. Sci. Eng. A Struct. 2013, 560, 781-786. [CrossRef]

10. Uyyala, S.-B.; Pathri, S. Investigation of tensile strength on friction stir welded joints of dissimilar aluminum alloys. Mater. Today Proc. 2020, 23, 469-473. [CrossRef]

11. Kahya, V.; Karaca, S.; Okur, F.-Y.; Altunışık, A.-C.; Aslan, M. Free vibrations of laminated composite beams with multiple edge cracks: Numerical model and experimental validation. J. Mech. Sci. 2019, 159, 30-42. [CrossRef]

12. Bussu, G.; Irving, P.-E. The role of residual stress and heat affected zone properties on fatigue crack propagation in friction stir welded 2024-T351 aluminium joints. Int. J. Fatigue 2003, 25, 77-88. [CrossRef]

13. Barrick, E.-J.; DuPont, J.-N. Mechanical properties and microstructural characterization of simulated heat-affected zones in $10 \mathrm{wt}$ pct Ni steel. Mater. Sci. Eng. A Struct. 2019, 748, 189-204. [CrossRef]

14. Sahin, M. Joining with friction welding of high-speed steel and medium-carbon steel. J. Mater. Process. Technol. 2005, 168, 202-210. [CrossRef]

15. Cheng, Z.; Huang, J.; Ye, Z.; Chen, Y.; Yang, J.; Chen, S. Microstructures and mechanical properties of copper-stainless steel buttwelded joints by MIG-TIG double-sided arc welding. J. Mater. Process. Technol. 2019, 265, 87-98. [CrossRef] 
16. Ye, Z.; Huang, J.; Gao, W.; Zhang, Y.; Cheng, Z.; Chen, S.; Yang, J. Microstructure and mechanical properties of 5052 aluminum alloy/mild steel butt joint achieved by MIG-TIG double-sided arc welding-brazing. Mater. Des. 2017, 123, 69-79. [CrossRef]

17. Pouranvari, M.; Abbasi, M. Dissimilar gas tungsten arc weld-brazing of Al/steel using Al-Si filler metal: Microstructure and strengthening mechanisms. J. Alloy. Compd. 2018, 749, 121-127. [CrossRef]

18. Üstündağ, Ö.; Gook, S.; Gumenyuk, A.; Rethmeier, M. Hybrid laser arc welding of thick high-strength pipeline steels of grade X120 with adapted heat input. J. Mater. Process. Technol. 2020, 275, 116358. [CrossRef]

19. Guo, W.; You, G.; Yuan, G.; Zhang, X. Microstructure and mechanical properties of dissimilar inertia friction welding of 7A04 aluminum alloy to AZ31 magnesium alloy. J. Alloy. Compd. 2017, 695, 3267-3277. [CrossRef]

20. Guo, W.; Wan, Z.; Jia, Q.; Ma, L.; Zhang, H.; Tan, C.; Peng, P. Laser weldability of TWIP980 with DP980/B1500HS/QP980 steels: Microstructure and mechanical properties. Opt. Laser Technol. 2020, 124, 105961. [CrossRef]

21. Thakare, J.-G.; Pandey, C.; Mahapatra, M.-M.; Mulik, R.-S. An assessment for mechanical and microstructure behavior of dissimilar material welded joint between nuclear grade martensitic P91 and austenitic SS304 L steel. J. Manuf. Process. 2019, 48, 249-259. [CrossRef]

22. Falkenreck, T.-E.; Klein, M.; Böllinghaus, T. Dynamic compressive behaviour of weld joints. Mater. Sci. Eng. A Struct. 2017, 702, 322-330. [CrossRef]

23. Kimura, M.; Suzuki, K.; Kusaka, M.; Kaizu, K. Effect of friction welding condition on joining phenomena, tensile strength, and bend ductility of friction welded joint between pure aluminium and AISI 304 stainless steel. J. Manuf. Process. 2017, 25, 116-125. [CrossRef]

24. Rao, G.-A.; Ramanaiah, N. Dissimilar metals AISI 304 steel and AA 2219 aluminium alloy joining by friction welding method. Mater. Today Proc. 2019, 19, 902-907. [CrossRef]

25. Li, P.; Sun, H.; Wang, S.; Hao, X.; Dong, H. Rotary friction welding of AlCoCrFeNi2.1 eutectic high entropy alloy. J. Alloy. Compd. 2020, 814, 152322. [CrossRef]

26. Ghias, S.-A.; Bindu, B.-V.-R.; Elanchezhian, C.; Siddhartha, D.; Ramanan, N. Analysis of The Friction Welding Mechanism of Low Carbon Steel - Stainless Steel And Aluminium-Copper. Mater. Today Proc. 2019, 16, 766-775. [CrossRef]

27. Khidhir, G.-I.; Baban, S.A. Efficiency of dissimilar friction welded 1045 medium carbon steel and 316L austenitic stainless steel joints. J. Mater. Technol. 2019, 8, 1926-1932. [CrossRef]

28. Shanjeevi, C.; Arputhabalan, J.; Pavithran, E.; Raju, B. Prediction of Optimized Friction Welding Parameter for Joining of Dissimilar Material using Friction Welding. Mater. Today Proc. 2019, 16, 838-842. [CrossRef]

29. Amraei, M.; Ahola, A.; Afkhami, S.; Bjork, T.; Heidarpour, A.; Zhao, X.-L. Effects of heat input on the mechanical properties of butt-welded high and ultra-high strength steels. Eng. Struct. 2019, 198, 109460. [CrossRef]

30. Meng, Y.; Li, X.; Gao, M.; Zeng, X. Microstructures and mechanical properties of laser-arc hybrid welded dissimilar pure copper to stainless steel. Opt. Laser Technol. 2019, 111, 140-145. [CrossRef]

31. Sahin, M.; Balasubramanian, N.; Misirli, C.; Akata, H.-E.; Can, Y.; Ozel, K. On properties at interfaces of friction welded near-nanostructured Al 5083 alloys. Int. J. Adv. Manuf. Technol. 2012, 61, 935-943. [CrossRef]

32. Liu, Z.; Fan, C.; Chen, C.; Ming, Z.; Liu, A.; Yang, C.; Lin, S.; Wang, L. Optimization of the microstructure and mechanical properties of the high nitrogen stainless steel weld by adding nitrides to the molten pool. J. Manuf. Process. 2020, 49, 355-364. [CrossRef]

33. Sahin, M. Joining of stailess steel and aluminium materials with friction welding. Int. J. Adv. Manuf. Technol. 2009, 41, 487-497. [CrossRef]

34. Masoumi, F.; Shahriari, D.; Monajati, H.; Cormier, J.; Flipo, B.-C.-D.; Devaux, A.; Jahazi, M. Linear friction welding of AD730 Ni-base superalloy: Process-microstructure-property interactions. Mater. Des. 2019, 183, 108117. [CrossRef]

35. Guo, Z.; Qiao, W.; Jia, X. Mechanical properties of butt weldments made with E5515-G electrodes at high temperature. J. Constr. Steel. Res. 2019, 159, 13-20. [CrossRef]

36. Yılmaz, M.; Çöl, M.; Acet, M. Interface properties of aluminum/steel friction-welded components. Mater. Charact. 2002, 49, 421-429. [CrossRef]

37. Chen, X.; Sun, W.; Li, X.; Wang, X.; Yan, H.; Li, K. Experimental and numerical studies on W-Cu functionally graded materials produced by explosive compaction-welding sintering. Fusion Eng. Des. 2018, 137, 349-357. [CrossRef] 
38. Avettand-Fènoël, M.-N.; Naji, K.; Pouligny, P. Brazing vs. diffusion welding of graded Fe based matrix composite and yttria stabilized zirconia. J. Manuf. Process. 2019, 45, 557-570. [CrossRef]

39. Wang, H.; Qin, Q. Thermal Analysis of a Functionally Graded Coating/Substrate System Using the Approximated Transfer Approach. Coatings 2019, 9, 51. [CrossRef]

40. Li, X.; Sun, J.-Y.; Dong, J.; He, X.-T. One-Dimensional and Two-Dimensional Analytical Solutions for Functionally Graded Beams with Different Moduli in Tension and Compression. Materials 2018, 11, 830. [CrossRef]

41. He, X.-T.; Li, Y.-H.; Liu, G.-H.; Yang, Z.-X.; Sun, J.-Y. Non-Linear Bending of Functionally Graded Thin Plates with Different Moduli in Tension and Compression and Its General Perturbation Solution. Appl. Sci. 2018, 8, 731. [CrossRef]

42. Zhang, X.; Li, Z.; Yu, J. The Computation of Complex Dispersion and Properties of Evanescent Lamb Wave in Functionally Graded Piezoelectric-Piezomagnetic Plates. Materials 2018, 11, 1186. [CrossRef]

43. Zhang, X.; Liang, S.; Han, X.; Li, Z. Computation of Propagating and Non-Propagating Lamb-Like Wave in a Functionally Graded Piezoelectric Spherical Curved Plate by an Orthogonal Function Technique. Materials 2018, 11, 2363. [CrossRef] [PubMed]

44. Koizumi, M. FDM activities in Japan. Compos. Part B Eng. 1996, 28, 1-4. [CrossRef]

45. Rajendran, T.P.; Hynes, N.R.J.; Nikolova, M.P.; Christopher, T.; Nikolov, D.J. Influence of heat treatment on friction-welded joints made of high-carbon high-chromium tool steel/low-carbon steel for tooling applications. J. Braz. Soc. Mech. Sci. 2020, 42-87. [CrossRef]

46. Malekzadeh, P.; Monajjemzadeh, M. Dynamic response of functionally graded beams in a thermal environment under a moving load. Mech. Adv. Mater. Struct. 2016, 23, 248-258. [CrossRef]

47. Layus, P.; Kah, P.; Khlusova, E.; Orlov, V. Study of the sensitivity of high-strength cold-resistant shipbuilding steels to thermal cycle of arc welding. Int. J. Mech. Mater. Des. 2018, 3, 13. [CrossRef]

(C) 2020 by the authors. Licensee MDPI, Basel, Switzerland. This article is an open access article distributed under the terms and conditions of the Creative Commons Attribution (CC BY) license (http://creativecommons.org/licenses/by/4.0/). 